\title{
Development of Student Worksheet for Infrared Technology Material Using Project Based Learning and Science Technology Engineering Mathematics Learning Model
}

\author{
Indah Melania, Arjuni Budi Pantjawati, Budi Mulyanti* \\ Department of Electrical Engineering Education \\ Universitas Pendidikan Indonesia \\ Bandung, Indonesia \\ arjunib@upi.edu, indahmelania@ student.upi.edu, *bmulyanti@upi.edu
}

\begin{abstract}
The rapid advancement of technology demands the ability of students to apply knowledge in solving problems that occur in society. This paper proposes the development of student worksheets for Infrared Technology material using the PjBLSTEM learning model. This study aims to determine the feasibility level of the student worksheets and students' responses after using that. This study involved two teachers and 43 students from 2 Vocational High School who were taking Electronic Circuit Application subjects. The level of feasibility was seen from the teacher's assessment, while the students' responses were seen from the questionnaire. The feasibility assessment instrument and student response questionnaire were prepared based on the Teaching Material Assessment Standards by the National Education Standards Agency (BSNP). This research was conducted using the ADDIE approach. Based on the teacher assessment, the feasibility level of the PjBL-STEM-based worksheets was categorized as very good or very feasible $(91 \%)$. Meanwhile, from the students' responses, the score was $87.61 \%$ in the very good or very satisfied category. The conclusion from this research is that the PjBL-STEM-based student worksheets are very suitable to be used as teaching materials for Infrared Technology material in the subject of Electronic Circuit Application.
\end{abstract}

Keywords—student worksheet, learning model, PjBL, STEM, infrared teknology

\section{INTRODUCTION}

With the rapid development of technology that has emerged in the 21st century, innovative and interdisciplinary talents are increasingly needed, especially those who can apply knowledge and techniques to solve problems that continue to arise in society and industry [1]. This condition encourages the STEM approach model that emphasizes the integration of Science, Technology, Engineering and Mathematics in learning to become increasingly popular throughout the world. The STEM approach is very much needed in learning science in honing cognitive, manipulative, designing, utilizing technology, and applying knowledge [2]. As a result, many learning models such as Project Based Learning (PjBL), Problem Based Learning, Real Situation Based Learning, and Inquiry Based Learning are combined with the STEM approach [3]. The approach of the four aspects of STEM makes problems that occur in the real world and $\mathrm{PjBL}$ learning into a harmonious partner. This approach is able to create an active learning method because all four aspects of STEM are needed simultaneously to solve problems. By integrating STEM into PjBL, students are encouraged to be able to put together abstract concepts from every aspect [4].

Vocational High Schools (SMK) in Indonesia have Graduate Competency Standards (SKL) which have been regulated in the Regulation of the Minister of Education and Culture No. 34 of 2018 concerning the National Vocational High School Education Standards, including understanding mathematics, understanding the concepts and principles of science, and the ability to use technology in carrying out tasks according to their expertise [5]. This is in line with the STEM approach, namely teaching and learning by integrating aspects of science, technology, engineering, and mathematics.

Audio Video technique is one of the skill competencies in SMK. In this skill competency, XI grade students are given topics about sensors with the sub-topic Infrared sensors in the Electronic Circuit Application Subject. Infrared is an electromagnetic ray that is widely used in the Telecommunication Field. Infrared technology is still widely used in everyday life, for example in television remotes. Another example being developed is long-wavelength digital infrared for remote sensing earth applications [6]. The wide use of infrared can be developed for future technological needs.

The success of a lesson depends both on the learning method and on the learning tools used. Books as teaching materials and learning resources are seen as an important factor 
in determining the success of the implementation of learning [7]. One of the teaching materials that can be used is student worksheet. Student worksheet is a student guide that is used to carry out investigative activities or problem solving. This worksheet contains a set of basic activities that must be carried out by students to maximize understanding in forming basic abilities that are in accordance with the indicators of learning achievement that must be taken [8].

In this study, we developed worksheet for STEM-based project-based learning (PjBL-STEM) model on infrared technology material in the subject of Electronic Circuit Application. In this worksheet, students were not only taught theory, but also practice in the form of projects, so that students got direct experience from the material being taught.

\section{METHODS}

This study used a quantitative research method with the ADDIE approach model. As the name implies, this model consists of 5 stages of implementation, namely analyze, design, develop, implement and evaluation [9].

\section{A. Analyze}

The analysis stage is the earliest stage carried out. At this stage we analyzed four things, namely: curriculum, PjBLSTEM learning model, materials, and teaching.

\section{B. Design}

At this stage we began designing worksheets for the PjBLSTEM learning model on infrared material, according to the results of the analysis carried out in the previous stage. The design of this worksheet consists of two parts, namely a guide for teachers and worksheets for students. The teacher's guide contains learning objectives, a list of tools and materials needed, steps, and tips for implementing learning. While the student worksheet consists of 5 stages of learning, namely the stage of reflection, researching, finding, applying, and communicating.

\section{Development}

The development stage is the stage of realizing the worksheets that were designed in the previous stage. First, we made worksheets for the PjBL-STEM learning model on infrared material according to the design structure. Second, we did a validation of teacher assessment instruments and student response instruments. Before this worksheet was implemented, a feasibility test was carried out by expert judgment as a basis for us to revise or improve student worksheet product.

\section{Implement}

At this stage, a product trial was conducted for students to find out the responses of students as users. In its implementation, this activity was carried out online via WhatsApp Group due to the constraints of the COVID-19 pandemic.

\section{E. Evaluation}

At the evaluation stage, we used level 1 evaluation, which only measured students' perceptions/responses such as the contents of the product, the tools and materials used in the product, the ease of using the product, and the teacher's explaining style [9]. At this stage we did not measure the effect of the student worksheet developed on learning outcomes. Teacher assessments and students' responses from the questionnaire were evaluated using a 5 levels Likert scale, then calculations were carried out to determine the feasibility level of the student worksheet and student satisfaction with the worksheet.

In this study, the data analysis technique used is descriptive statistical techniques. This technique is a method for analyzing data by describing the data as it is without generalizing [10]. The purpose of the analysis in this study is to obtain research results in the form of the feasibility level of the teaching material product. The instrument used was a Google Form questionnaire for teacher assessment and student responses. The percentage category for teacher assessment and student responses is listed in Table 1 .

TABLE I. RAting PerCentage CATEgory [11]

\begin{tabular}{|l|l|}
\hline \multicolumn{1}{|c|}{ Percentage of feasibility and response $(\boldsymbol{\%})$} & \multicolumn{1}{c|}{ Category } \\
\hline $80,0<\mathrm{P} \leq 100$ & Very good \\
\hline $60,0<\mathrm{P} \leq 80,0$ & Good \\
\hline $40,0<\mathrm{P} \leq 60,0$ & Fair \\
\hline $20,0<\mathrm{P} \leq 40,0$ & Poor \\
\hline
\end{tabular}

\section{RESULTS AND DISCUSSION}

This research produced teaching material products in the form of PjBL-STEM-based worksheets for Infrared Technology material in the subject of Application of Electronic Circuits in the competency of Audio Video Engineering expertise. There were 2 parts developed, namely, a guide for teachers and worksheet for students. This worksheet was based on PjBL-STEM learning with stages: reflection, researching, discovering, applying, and communicating.

\section{A. Analyze}

Curriculum analysis was carried out to identify core competencies, basic competencies and select materials that were appropriate to the curriculum at the research site. Infrared technology material was chosen because it is widely used and easy to implement through examples in everyday life, so that students can experiment directly through the activities presented in the worksheet. After analyzing the material, we analyzed the learning model that will be used in the worksheets. PjBL-STEM is a learning model that can make students experience the learning process directly by providing learning projects that can hone cognitive, manipulative, design, utilize technology and application of knowledge [2]. In addition, the selection of the PjBL-STEM learning model was based on one of the Graduate Competency Standards (SKL) which has been regulated in the Regulation of the Minister of 
Education and Culture No. 34 of 2018 concerning the National Vocational High School Education Standards, including having an understanding of mathematics, understanding the concepts and principles of science, and having the ability to use technology in carrying out tasks according to their expertise [5]. Finally, analyze teaching materials. The teaching materials developed in this study were Student Worksheets. Based on preliminary interviews with students, infrared sub-topic learning, based only on book and internet learning resources, did not use the PjBL-STEM learning model LKS. In this LKS, students were not only taught in theory, but also practice in the form of projects.

\section{B. Design}

This worksheet was designed based on the learning stages of PjBL-STEM, namely Reflection, Researching, Finding, Applying, and Communicating [12]. In designing this worksheet, we designed the cover page and the content framework of the worksheet. This content framework was adapted to the PjBL-STEM material and learning stages and consists of an introduction, student reference sheet, student worksheet, and teacher's guide.

\section{Development}

We carried out the process of making and developing the PjBL-STEM learning model worksheets according to the results of the due diligence of the expert judgment which reviewed both in terms of the material and the media, based on the Standards for Assessment of Teaching Materials by BNSP. This development aimed to obtain the final form of the PjBLSTEM learning model LKS.

The Introduction section contains learning focus, learning synopsis, learning objectives, learning outcomes, learning activities, learning resources / materials, internet connections, suggested reading, and writing activities. The student reference sheet section contains material about infrared and its application in equipment or systems. Its subsections consist of the definition of infrared, infrared applications, and methods of remote-control development. Each material was equipped with pictures to make it easier for students to understand the material.

The Student Worksheet section: Engineering Research contains the first to third PjBL-STEM learning stages, namely reflection, research, and discovery. In the reflection stage, problems associated with everyday life were presented regarding infrared transmission on the TV remote. The TV remote sensor will be blocked by materials that have been provided such as white paper, black paper, plastic, a glass of water, a glass of milk and others. Students in groups will discuss to answer the problems given and wrote them down on the sheet provided. At this stage, a picture of the TV remote tester circuit was presented along with the steps for making it. Students will make and then test the circuit that has been made using the tv remote to turn on the buzzer and LED on the circuit. After the series was successful, two tests were carried out. This test was carried out to prove the results of the previous stage, namely the reflection stage. The first stage of testing used a TV remote tester circuit that has been made and the second test used a television. At this stage, questions were presented to evaluate the results of the group from the experimental activities that have been carried out by students. In addition to evaluating, the questions presented will be provision for the next stage.

The Student Worksheet: Engineering Challenge section contains the fourth and fifth PjBL-STEM learning stages, namely applying and communicating. At the applying stage, students in groups were given the challenge of compiling a plan to operate the television using an infrared remote control located in the corner of the room or in another room. Students wrote down the plan on the table provided. Then the plan was realized and tested. After the testing phase was complete, students must answer questions to evaluate the results of this application stage. At the communicating stage, students made a presentation on the results of the previous stage, then answered the reflection questions given.

The PjBL-STEM based student worksheet validation process was carried out by an expert judgment to assess the feasibility of the worksheets that have been made. Assessment was carried out both on the appearance of the worksheets and the content of the material. The assessment included aspects of the quality of content, aspects of appearance and aspects of language.

\section{Implementation}

In the implementation stage, the distribution and testing of the final revised worksheets were carried out to XI grade students of Audio Video Engineering SMKN 4 and SMKN 6 Bandung, West Java, based on the learning stages of PjBLSTEM, namely Reflection, Researching, Finding, Applying, and Communicating.

At the Reflection stage, we first guided students to read the Student Reference Sheet section on the worksheet. To make it easier to understand material about infrared technology, we sent videos that we had made to students. Then we provided problems for the students to discuss. The challenges of the problems given in the worksheet were challenges that allow them to be applied in real life [13]. At the researching stage, the activity was divided into 2 parts, namely making a TV remote tester circuit and testing contained in worksheet pages 8 and 9 . The use of technology began to be integrated in this stage through circuit manufacturing activities. Another technology integration was the use of the internet to find information about the manufacture of a TV remote tester circuit. At the Finding stage, students answered the questions on the worksheet page 10 as an evaluation of the previous stage and a reflection for the next stage. To answer the questions on the worksheet, scientific imagineering was needed. The scientific imagination process can foster students' STEM literacy, because this process is in accordance with the characteristics of STEM learning which can foster higher-order thinking skills, problemsolving abilities and curiosity [14]. The fourth stage, namely Applying, this stage was the application of the engineering 
design process activities that characterize PjBL-STEM learning. Students started designing by making plans to operate the television using an infrared remote control located in another room. The last stage was communicating, students were asked to convey the results obtained during the activities contained in the worksheet.

\section{E. Evaluate}

At this stage we processed the data obtained from 2 teachers and 43 students of class XI Audio Video Engineering 1 SMKN 4 Bandung and SMKN 6 Bandung. Furthermore, we averaged the percentages to obtain the final feasibility percentage value. The data on the results of the assessment for each aspect are listed in Table 2.

TABLE II. FEASIBILITY VALUE RESULT

\begin{tabular}{|l|l|l|c|}
\hline Assessment aspects & Rating average & Percentage (\%) & Category \\
\hline Content feasibility & 4,667 & $93,33 \%$ & Very good \\
\hline Display feasibility & 4,571 & $91,43 \%$ & Very good \\
\hline Language eligibility & 4,25 & $85 \%$ & Very good \\
\hline Assessment average precentage & $91 \%$ & Very good \\
\hline
\end{tabular}

From the assessment, the percentage of content feasibility aspect was $93.33 \%$, the display feasibility aspect was $91.43 \%$, and the language eligibility aspect was $85 \%$. Thus, the average percentage of the assessment was $91 \%$. Based on Table 1, the student worksheets that were assessed are in the very good category because they are between $80.10 \%-100.0 \%$.

From the trials at the implementation stage, student response data were obtained in each aspect, as shown in Table 3.

TABLE III. STUDENTS RESPONSE RESULT

\begin{tabular}{|l|l|l|l|}
\hline Assessment aspects & Rating average & Percentage (\%) & Category \\
\hline Content & 4,320 & $86,40 \%$ & very satisfied \\
\hline Display & 4,428 & $88,56 \%$ & very satisfied \\
\hline Learning & 4,381 & $87,63 \%$ & very satisfied \\
\hline Students response average precentage & $87,61 \%$ & very satisfied \\
\hline
\end{tabular}

Based on Table 3, the overall responses of students on aspects of the quality of content, appearance, learning, and the percentage of students' responses can be concluded that students are very satisfied in every aspect stated because they are in the range $80.10 \%-100.0 \%$.

\section{CONCLUSION}

Student worksheet for Infrared Technology using PjBLSTEM learning model has been successfully developed using the ADDIE approach. The worksheets developed consist of two books, namely Student Worksheets and Teachers' Guidelines. Based on the results of the assessment, the feasibility level of the PjBL-STEM-based worksheets is categorized as very good or is feasible to be applied for Infrared Technology material in the subject of Electronic Circuit Application. Meanwhile, the response of students at SMKN 4 Bandung \& SMKN 6 Bandung, West Java, after a trial using PjBL-STEM-based worksheets gave a very satisfied response $(87.61 \%)$ on all aspects proposed and applied as Infrared Technology learning materials.

\section{REFERENCES}

[1] Y. Li and X. Zhai, "Implementing high school mathematics and engineering competencies: The RDFZ integrated STEM research program and practice," IEEE Integrated STEM Education Conference (ISEC), pp. 22-29, 2018.

[2] R.M. Capraro, M.M. Capraro, and J.R. Morgan, STEM project-based learning: An integrated science, technology, engineering, and mathematics (STEM) approach. Springer Science \& Business Media, 2013.

[3] M. LaForce, E. Noble, and C. Blackwell, "Problem-Based Learning (PBL) and Student Interest in STEM Careers: The Roles of Motivation and Ability Beliefs," Education Sciences, vol. 7, no, 4, pp. 92, 2017.

[4] S.T. Force, Innovate: A blueprint for science, technology, engineering, and mathematics in California public education, CA: Californians Dedicated to Education Foundation, 2014

[5] Peraturan Menteri Pendidikan dan Kebudayaan Republik Indonesia Nomor 34 Tahun 20182018 Tentang Standar Nasional Pendidikan Sekolah Menengah Kejuruan/Madrasah Aliyah Kejuruan. [Online] Retrieved

https://jdih.kemdikbud.go.id/arsip/Permendikbud\%20Nomor\%2034\%20 Tahun\%202018.pdf

[6] S. Gunapala, S. Rafol, D. Ting, A. Soibel, A. Khoshakhlagh, S. Keo, and K.K. Choi, "Infrared Digital Focal Plane Arrays for Earth Remote Sensing Instruments," Multidisciplinary Digital Publishing Institute Proceedings, vol. 27, no. 1, p. 54, 2019.

[7] S. Kaymakc and A.C. War, A Review of Studies on Worksheets in Turkey, 2012

[8] T. Trianto, Model pembelajaran terpadu, Jakarta: Bumi Aksara, 2010

[9] R.M. Branch, Instructional design: The ADDIE approach (Vol. 722). Springer Science \& Business Media, 2009

[10] P.A. Jargowsky and R Yang, "Descriptive and Inferential Statistics," International Journal of Research \& Methodology in Social Science, vol. 1, no. 1, pp. 22, 2015.

[11] M.B.A. Riduwan, Skala pengukuran variabel-variabel penelitian, Bandung: Alfabeta, 2013

[12] D. Laboy-rush, Integrated STEM Education through Project-Based Learning. STEM Solutions Manager, Orlegon: Learning.com, 2010.

[13] C.M. Cunningham and C.P. Lachapelle, "Designing engineering experiences to engage all students," Engineering in pre-college settings: Synthesizing research, policy, and practices, pp. 117-142, 2014.

[14] S. Techakosit and P. Nilsook, "The learning process of scientific imagineering through AR in order to enhance STEM literacy,"7. International Journal of Emerging Technologies in Learning (iJET), vol. 11 , no. 07 , pp. 57-63, 2016. 